\title{
Seasonal shift of foraging habitat among farmland breeding Eurasian Curlews Numenius arquata
}

\author{
Adriaan de Jong \\ Department of Wildlife, Fish, and Environmental Studies, Swedish University of Agricultural Sciences, SE-901 83 Umeå, Sweden \\ E-mail: adriaan.de.jong@slu.se
}

\begin{abstract}
The importance of landscape heterogeneity for farmland birds is widely recognized, but the underlying processes remain unclear. Here I investigate the distribution of foraging and non-foraging Eurasian Curlews over agricultural treatment classes during the breeding season. The results show that Eurasian Curlews used grassland for foraging early in the breeding season but shifted to cereal fields later. Contrastingly, the distribution of non-foraging Eurasian Curlews over treatment classes rarely deviated from random. I conclude that relative foraging habitat quality changed among the investigated agricultural treatment classes and that landscapes containing more than one treatment class have higher overall quality for Curlews. Preserving or creating landscapes with a mix of different kinds of commercially managed fields is a relatively cheap and easily accepted farmland bird conservation measure.
\end{abstract}

Key words: Landscape heterogeneity; spatio-temporal distribution; habitat quality; conservation; waders; soil penetrability

\section{INTRODUCTION}

When conservation programs fail to halt the decline of farmland biodiversity, another look in the "toolbox" is required (Whittingham 2007, Kleijn et al. 2011). Landscape heterogeneity is increasingly recognized as an important factor in maintaining farmland biodiversity (Benton et al. 2003, Herzon \& O'Hara 2007). Due to its multiple dimensions and scales, the concept of landscape heterogeneity is complex, and the links between heterogeneity components and biodiversity are only partially understood (Tscharntke et al. 2005, Fahrig et al. 2011). Nevertheless, various heterogeneity-based farmland bird conservation measures have already earned their merits (Wilson et al. 2005, Schekkerman et al. 2008), but these measures reduce crops and increase costs, and thus rely on financial compensation to farmers.

The model species of this study is the Eurasian Curlew Numenius arquata (hereafter "Curlew"), a conspicuous and common farmland bird in northern Sweden (Svensson et al. 1999). In boreal agricultural landscapes, Curlews nest and forage on farmed fields and set-asides (Berg 1992, Valkama et al. 1998), but avoid the surrounding forest habitat. Foraging Curlews take their prey from the soil surface or by probing (Cramp \& Simmons 1983), and during probing, they regularly bury their entire bill into the soil (Zwarts \& Esselink 1989). In studies in Sweden (Berg 1993) and Finland (Currie and Valkama 1998), soil-living invertebrates were the main food source for farmland breeding Curlews.

Under the constraints of reproductive effort, adult Curlews are likely to optimize foraging efficiency during the breeding season, and thus can be expected to shift between habitat patches in response to temporal changes in relative foraging habitat quality. In this study I test whether the distribution of Curlews over agricultural treatment classes changed during the breeding season and whether foraging and non-foraging Curlews displayed different temporal responses.

\section{MATERIAL AND METHODS}

The study was performed in the vicinity of the city of Umeå $\left(63^{\circ} 49^{\prime} \mathrm{N}, 20^{\circ} 16^{\prime} \mathrm{E}\right)$, Västerbotten county in northern Sweden during spring and early summer 2007. In this area, farmland is well-drained, open and readily accessible by roads. Dairy and pork are the main farm products, and ley (sown perennial grasses) and barley for fodder are the main crops. Due to harsh winter conditions, farming does not start before midMay and only spring sown cereals are grown (Figure 1).

The agricultural fields for this study were selected in a two step process. First, a set of 12 road sections was chosen randomly from the many roads crossing farmland within the study area. The distance between these road sections was $>0.5 \mathrm{~km}$. Second, all fields along these road sections were selected under the condition that (a) they were fully visible (= no hidden 


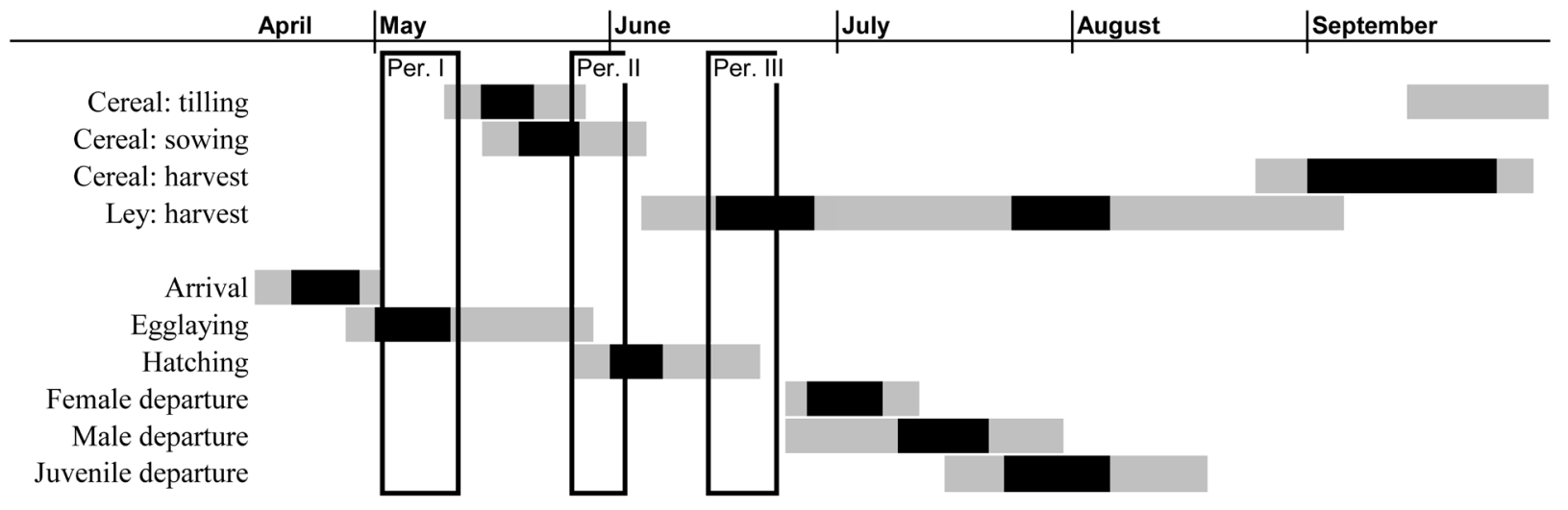

Figure 1. Schematic timetable of farming and the breeding season of Eurasian Curlews in northern Sweden. Main periods in black, less intensive periods in grey. In reality, the transitions between intensive and less intensive periods are gradual, not sharp. Information based on personal observation during $30+$ years of ornithological studies in the area and its surroundings. Vertical boxes mark the three periods of observation (Periods I - III).

parts) and (b) their agricultural treatment did not change over the study period. The result was a fixed set of 273 fields with a total area of 448 ha. These fields were under four types of agricultural treatment: ley, cereal, pasture and set-aside (rough grassland), covering 69, 22,4 and $5 \%$ of the total area respectively. Only cereal fields were tilled during the study period (Figure 1).

Individual fields were scanned for adult Curlews twice during each of three periods in 2007: May 2-11 (Period I), May 26 -June 2 (Period II) and June 14-22 (Period III). All observations were made during daytime (7AM - 5 PM) and subsequent visits were always more than three days apart. The start of Period I was chosen to avoid the presence of late migrants and Period III ended shortly before the onset of post-breeding migration (Cramp \& Simmons 1983, Figure 1). In order to minimize the risk of influencing the behaviour of the Curlews, I made all initial observations from a car using a telescope (30x) and/or binoculars (10x). For each field and each visit I documented agricultural treatment, and number and behaviour ("foraging" and "non-foraging") of adult Curlews. Foraging birds walked slowly alternating pecking and probing, and this behaviour could be distinguished within a few seconds of observation from other behaviour, e.g. resting, preening, social interactions and alertness. Based on body size and bill-shape (Cramp \& Simmons 1983), $63 \%$ of the Curlews could be sexed. Flying birds were neglected, and multiple counts of the same individual per visit were avoided, because all the Curlews within the field clusters could be observed simultaneously. I controlled for undetected birds by walking over a random selection of newly scanned fields $(\mathrm{N}=257$, total area of $380 \mathrm{ha}$ ). These control walks were made so that all parts of the field came within $50 \mathrm{~m}$ of the observer, a distance at which Curlews are efficiently flushed (pers. obs.).

For each period, I created $95 \%$ confidence intervals of the expected numbers of foraging and non-foraging Curlews separately for each treatment class, based on random binomial probability distribution in relation to area (Figure 2). Observed numbers were compared with the corresponding confidence limits.

I used R version 2.13.1 (R Development Core Team 2011) with the lattice package version 0.18-3 (Sarkar 2008 ) for statistical analyses ( $\chi^{2}$ for given probabilities, Pearson's $\chi^{2}$ and Fisher's exact tests) and plotting.

\section{RESULTS}

The sample size of observed Curlews was 257 (78, 79 and 100 during Period I-III respectively), of which 123 (48\%) were foraging. Total numbers and proportion of foraging birds did not differ significantly between periods $\left(\chi_{2}^{2}\right.$ for given probabilities $=3.6, P=0.17$ and 4.6, $P$ $=0.10$ respectively). The control program revealed that two birds $(0.8 \%)$ had been overlooked during initial scanning. The proportion of treatment classes among controlled fields did not differ from the full set of studied fields $\left(\chi_{3}^{2}\right.$ for given probabilities $\left.=2.4, P=0.48\right)$. Given that individual birds were counted only once during each of the six observations within a field cluster and very few birds were overlooked, this study is based on the habitat choices of at least $39(=78 / 2), 40$ and 50 individual Curlews during Period I-III respectively.

The proportions of males differed neither between periods $\left(\chi_{2}^{2}\right.$ for given probabilities $=1.13, P=0.57$, male/female ratio $=1.0,1.3$ and 1.5 for $\mathrm{N}=49,66$ and 65 during Period I-III respectively) nor, for foraging birds, between leys and cereal fields (Fisher's exact $P=$ 1.0 for all periods, $\mathrm{N}_{\text {males }}=47$ and $\mathrm{N}_{\text {females }}=47$ ). 


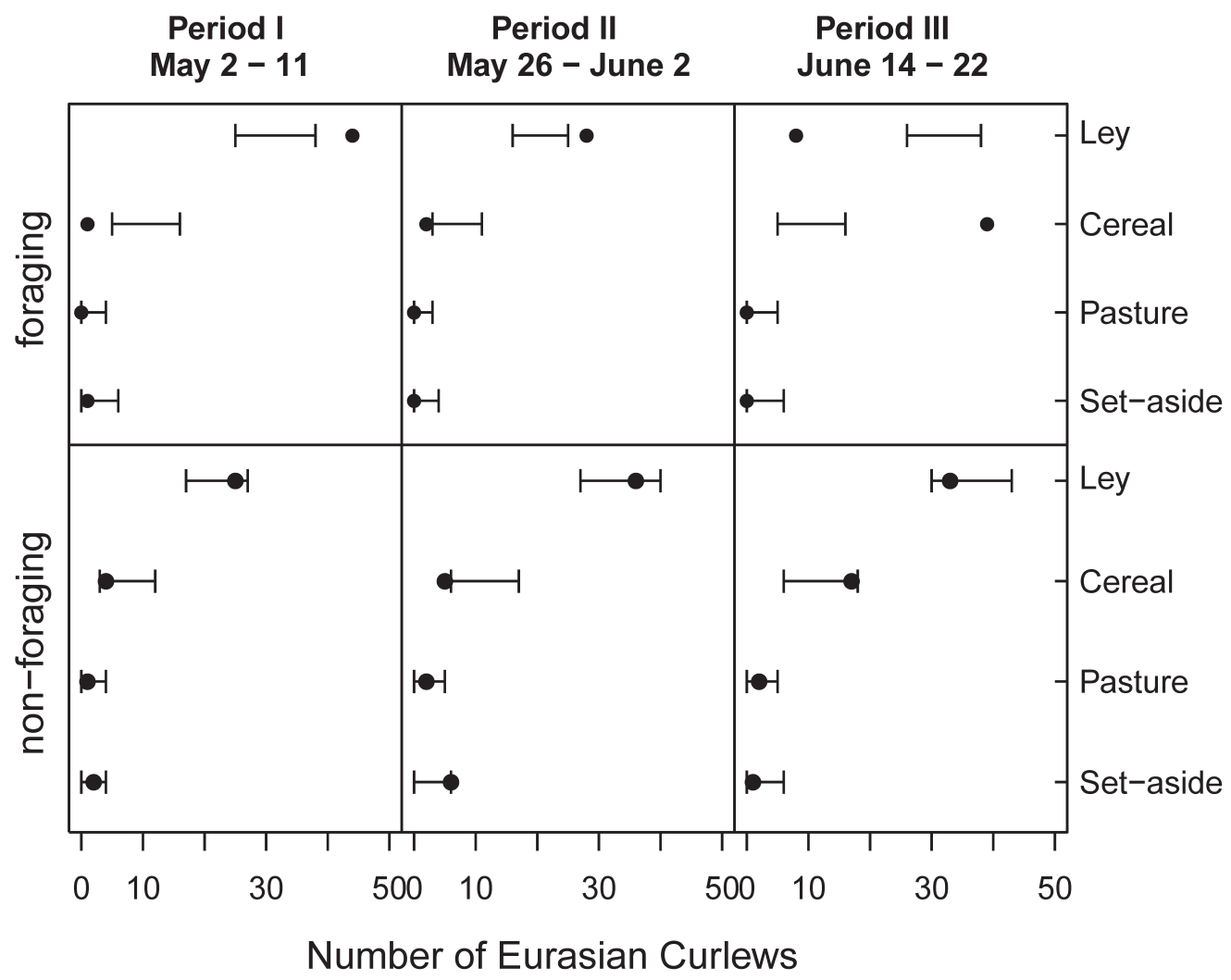

Figure 2. Observed numbers (dots) of foraging and non-foraging Eurasian Curlews over agricultural treatment classes and periods compared with $95 \%$ confidence intervals (CI's) under random spatial (binomial) distribution (bars). Observed numbers outside the $95 \%$ CI's indicate significantly $(\mathrm{P}<0.05)$ lower or higher numbers than could be expected from chance alone.

Pastures and set-asides together covered less than $9 \%$ of total area and hosted less than $6 \%$ of the observed Curlews. Neither non-randomness nor temporal patterns were apparent (Figure 2), but the observed numbers were too small for statistical testing.

Over the three periods, the observed numbers on leys were 44, 28 and 8 for foraging birds and 25, 36 and 33 for non-foraging birds. On cereal fields the corresponding numbers were 1, 2 and 39, and 4, 5 and 17. Compared with random distribution over available area of leys and cereal, only foraging Curlews showed consistently significant $(P<0.05)$ deviations from the expected numbers; biased towards leys during Period I and II and towards cereal fields during Period III (Figure 2).

A temporal change in relative abundances on leys and cereal fields occurred among foraging and nonforaging Curlews, but was more pronounced for the former $\left(\chi_{2}^{2}=80.0, P<0.0001\right)$ than the latter behavioural class $\left(\chi_{2}^{2}=7.7, P=0.02\right)$. The ley-cereal balance did not change between Period I and II (Fisher's exact odds ratio $(\mathrm{FEOR})=3.1, P=0.56$ for foraging and $\mathrm{FEOR}=$ $0.9, P=1$ for non-foraging), but did so between Period II and III (FEOR $=62.5, P<0.0001$ for foraging and $\mathrm{FEOR}=3.7, P=0.03$ for non-foraging).

\section{DISCUSSION}

The observed shift in the distribution of foraging Curlews over treatment classes implies that relative foraging habitat quality of leys and cereal fields changed over the breeding season, and that mosaic landscapes with ley and cereal may represent greater overall habitat quality for Curlews than landscapes with just one of these treatment classes. Even nonforaging Curlews changed their preference for leys and cereal fields over the breeding season, but this change was only moderately significant, and in addition, non-foragers' distribution over treatment classes were spatially (near) random during all periods.

The shift of habitat choice of the foraging Curlews seems to be an adjustment of individual birds to changing foraging conditions. Alternatively, the initial population was replaced with Curlews with different preferences. To avoid population turnover, I conducted the study between the migration periods (Figure 1), and indeed a stable Curlew population was suggested by similarity over Periods I-III of (a) total numbers, (b) proportions of foraging birds and (c) proportion of males.

An important driver of the foraging habitat shift 
from leys to cereal fields may have been a change in soil penetrability, because final tilling (harrowing) of cereal fields occurred between Periods II and III and produced loose soils when non-tilled soils gradually became compacted due to early-summer drought conditions and efficient drainage. Soil-living prey in non-tilled fields may have become virtually inaccessible for foraging Curlews, especially when the prey moved to greater depth due to the drying of the upper layers. The importance of soil penetrability for foraging waders has been shown in Dunlin Calidris alpina (Mouritsen \& Jensen 1992, Taft et al. 2008), Sanderling Calidris alba (Myers et al. 1980) and Common Snipe Gallinago gallinago (Green et al. 1990). Also, Congdon \& Catterall (1994) and Finn et al. (2008) found that Eastern Curlews Numenius madagascariensis wintering in Australia chose foraging habitat on the basis of soil penetrability rather than of prey abundance. Even Gilroy et al. (2008) observed a positive effect of soil penetrability on the abundance of farmland breeding Yellow Wagtails Motacilla flava, but in this surface/aerial feeding species, soil penetrability was probably associated with prey abundance rather than the physics of foraging.

Even in this study, the role of prey abundance cannot be ruled out (but see Berg 1993). Other potential drivers are prey-shift, disturbance, predation risk and chick-guarding duties, and further studies are needed to unravel the relative importance of these factors.

For farmland bird conservation, my results show that mixing commercially managed crops in a medium grained agricultural landscape may enhance choice and hence overall foraging habitat quality for Curlews. Conservation measures based on increasing heterogeneity by commercial management should be relatively cheap to implement and easily accepted by farmers.

Acknowledgements. Thanks to Kjell Leonardsson for statistical advice. Åke Berg, Åke Lindström, Inga-Lill Persson, Göran Spong, Carl-Gustaf Thulin, Jari Valkama, Fredrik Widemo, Yvonne Verkuil, Gaute Bø Grønstøl and an anonymous reviewer contributed with valuable comments on earlier versions of the manuscript.

Sammendrag. Sesongmessig forandring i habitat hos storspove som hekker i jordbrukslandskap. Det er generelt akseptert at et sammensatt landskap er gunstig for fugler som lever i jordbruksområder, men den bakenforliggende forklaringen er ofte uklar. I dette studiet undersøkes forekomst av beitende og ikke-beitende storspover i hekketiden på områder med ulik markbruk nær Umeå, Sverige. Resultatene viste at storspoven benyttet grasmarker til fødesøk tidlig i hekkesesongen, men skiftet i en viss grad til kornåkre senere. Til forskjell fra dette mønsteret var ikke-beitende storspover som oftest tilfeldig fordelt i forhold til dyrkningsform. Det konkluderes med at kvaliteten som fødesøksområde endrer seg ulikt med sesongen for de ulike dyrkningsformene, og at tilgjengelighet på arealer med mer enn én dyrkningsform er gunstig for storspoven. $\AA$ opprettholde eller skape en blanding av ulike typer dyrket mark kan vise seg å være et relativt billig og lett akseptabelt forvaltningstiltak for fugler $i$ jordbrukslandskap.

\section{REFERENCES}

Benton, T.G., Vickery, J.A. \& Wilson, J.D. 2003. Farmland biodiversity: is habitat heterogeneity the key? Trends Ecol. Evol. 18: 182-188.

Berg, A. 1992. Habitat selection by breeding curlews Numenius arquata on mosaic farmland. Ibis 134: $355-$ 360.

Berg, A. 1993. Food resources and foraging success of curlews Numenius arquata in different farmland habitats. Ornis Fennica 70: 22-31.

Congdon, B.C. \& Catterall, C.P. 1994. Factors influencing the Eastern Curlew's distribution and choice of foraging sites among tidal flats of Moreton Bay, South-eastern Queensland. Wildlife Res. 21: 507-518.

Cramp, S. \& Simmons, K.E.L. (eds..) 1983. The Birds of the Western Palearctic. Vol. 3. Oxford University Press, Oxford, UK.

Currie, D. \& Valkama, J. 1998. Limited effects of heavy metal pollution on foraging and breeding success in the Curlew (Numenius arquata). Environ. Pollu. 101: 253-261.

Fahrig, L., Baudry, J., Brotons, L., Burel, F.G., Crist, T.O., Fuller, R.J., Sirami, C., Siriwardena, G.M. \& Martin, J-L. 2011. Functional landscape heterogeneity and animal biodiversity in agricultural landscapes. Ecol. Lett. 14: 101-112.

Finn, P.G., Catterall, C.P. \& Driscoll, P.V. 2008. Prey versus substrate as determinants of habitat choice in a feeding shorebird. Estuar. Coast. Shelf S. 80: 381-390.

Gilroy, J.J., Anderson, G.Q.A., Grice, P.V., Vickery, J.A., Bray, I., Watts, P.N. \& Sutherland, W.J. 2008. Could soil degradation contribute to farmland bird declines? Links between soil penetrability and the abundance of Yellow Wagtails Motacilla flava in arable fields. Biol. Conserv. 141: 3116-3126.

Green, R.E., Hirons, G.J.M. \& Cresswell, B.H. 1990. Foraging habitats of female Common Snipe Gallinago gallinago during the incubation period. J. Appl. Ecol. 27: 325-335.

Herzon, I. \& O'Hara, R.B. 2007. Effects of landscape complexity on farmland birds in the Baltic States. Agric. Ecosyst. Environ. 118: 297-306.

Kleijn, D., Rundlöf, M., Scheper, J., Smith, H.G. \& Tscharntke, T. 2011. Does conservation on farmland contribute to halting the biodiversity decline? Trends Ecol. Evol. 26: 474-481.

Mouritsen, K.N. \& Jensen, K.T. 1992. Choice of microhabitat in tactile foraging Dunlins Calidris alpina: the importance of sediment penetrability. Mar. Ecol. Prog. Ser. 85: 1-8. 
Myers, J.P., Williams, S.L. \& Pitelka, F.A. 1980. An experimental analysis of prey availability for Sanderlings (Aves, Scolopacidae) feeding on sandy beach Crustaceans. Can. J. Zool. 58: 1564-1574.

R Development Core Team (2011). R: A language and environment for statistical computing. R Foundation for Statistical Computing, Vienna, Austria. ISBN 3-90005107-0, URL http://www.R-project.org/.

Sarkar, D. 2008. Lattice: Multivariate data visualization with R. Springer, New York, USA.

Schekkerman, H., Teunissen, W. \& Oosterveld, E. 2008. The effect of "mosaic management" on the demography of Black-tailed Godwit Limosa limosa on farmland. J. Appl. Ecol. 45: 1067-1075.

Svensson, S., Svensson, M. \& Tjernberg, M. 1999. Svensk fågelatlas. [The Swedish Breeding Bird Atlas.] Vår Fågelvärld, suppl. 31. Stockholm. (In Swedish)

Taft, O.W., Sanzenbacher, P.M. \& Haig, S.M. 2008. Movements of wintering Dunlin Calidris alpina and changing habitat availability in an agricultural wetland landscape. Ibis 150: 541-549.
Tscharntke, T., Klein, A.M., Kruess, A., Steffan-Dewenter, I. \& Thies, C. 2005. Landscape perspectives on agricultural intensification and biodiversity - ecosystem service management. Ecol. Letters 8: 857-874.

Valkama, J., Robertson, P. \& Currie, D. 1998. Habitat selection by breeding Curlews (Numenius arquata) on farmland: the importance of grassland. Ann. Zool. Fenn. 35: 141-148.

Whittingham, M.J. 2007. Will agri-environment schemes deliver substantial biodiversity gain, and if not why not? J. Appl. Ecol. 44: 1-5.

Wilson, J.D., Whittingham, M.J. \& Bradbury, R.B. 2005. The management of crop structure: a general approach to reversing the impacts of agricultural intensification on birds? Ibis 147: 453-463.

Zwarts, L. \& Esselink, P. 1989. Versatility of male Curlews Numenius arquata preying upon Nereis diversicolor: deploying contrasting capture modes dependent on prey availability. Mar. Ecol. Prog. Ser. 56: 255-269.

Received 9 January 2012. Accepted 6 February 2012 